\title{
Techno-economic analysis of sorption-enhanced steam methane reforming in a fixed bed reactor network integrated with fuel cell
}

\author{
Giuseppe Diglio $^{\mathrm{a}}$, Dawid Hanak ${ }^{\mathrm{b}}$, Piero Bareschino ${ }^{\mathrm{a}}$, Erasmo Mancusi ${ }^{\mathrm{a}}$, \\ Francesco Pepe $^{\mathrm{a}}$, Fabio Montagnaro ${ }^{\mathrm{c}}$, Vasilije Manovic ${ }^{\mathrm{b}, *}$
}

a Dipartimento di Ingegneria, Università degli Studi del Sannio, Piazza Roma 21, 82100 Benevento, Italy

${ }^{\mathrm{b}}$ Combustion and CCS Centre, Cranfield University, Cranfield MK43 0AL, United Kingdom

${ }^{c}$ Dipartimento di Scienze Chimiche, Università degli Studi di Napoli Federico II, Complesso Universitario di Monte Sant'Angelo, 80126 Napoli, Italy

Journal of Power Sources, 364, 41-51

*Corresponding Author: V. Manovic (v.manovic@cranfield.ac.uk) 


\begin{abstract}
Sorption-enhanced steam methane reforming (SE-SMR) is a promising alternative for $\mathrm{H}_{2}$ production with inherent $\mathrm{CO}_{2}$ capture. This study evaluates the techno-economic performance of SESMR in a network of fixed beds and its integration with a solid oxide fuel cell (SE-SMR-SOFC) for power generation. The analysis revealed that both proposed systems are characterised by better economic performance than the reference systems. In particular, for SE-SMR the levelised cost of hydrogen is $1.6 € \cdot \mathrm{kg}^{-1}$ and the cost of $\mathrm{CO}_{2}$ avoided is $29.9 € \cdot \mathrm{tco}^{-1}\left(2.4 € \cdot \mathrm{kg}^{-1}\right.$ and $50 € \cdot \mathrm{tcO}^{-1}$, respectively, for SMR with $\mathrm{CO}_{2}$ capture) while for SE-SMR-SOFC the levelised cost of electricity is $0.078 € \cdot \mathrm{kWh}^{-1}$ and the cost of $\mathrm{CO}_{2}$ avoided is $36.9 € \cdot \mathrm{tcO}^{-1}\left(0.080 € \cdot \mathrm{kWh}^{-1}\right.$ and $80 € \cdot \mathrm{tcO}^{-1}$, respectively, for natural gas-fired power plant with carbon capture). The sensitivity analysis showed that the specific cost of fuel and the capital cost of fuel cell mainly affect the economic performance of SE-SMR and SE-SMR-SOFC, respectively. The daily revenue of the SE-SMR-SOFC system is higher than that of the natural gas-fired power plant if the difference between the carbon tax and the $\mathrm{CO}_{2}$ transport and storage cost is $>6 € \cdot \mathrm{tCO}^{-1}$.
\end{abstract}

Keywords: Sorption-enhanced steam methane reforming; Solid oxide fuel cell; Natural gas-fired power plant; Techno-economic analysis; $\mathrm{CO}_{2}$ capture 


\section{Nomenclature}

$\mathrm{AC} \quad$ Cost of $\mathrm{CO}_{2}$ avoided, $€ \cdot \mathrm{tCO}^{-1}$

Acond Condenser heat transfer area, $\mathrm{m}^{2}$

$\mathrm{cbb} \quad$ Specific cost of burner, $€ \cdot \mathrm{kW}_{\mathrm{th}^{-1}}$

$\mathrm{c}_{\mathrm{cc}} \quad$ Specific cost of condenser, $€ \cdot \mathrm{m}^{-2}$

$\mathrm{cCaO} \quad$ Specific cost of sorbent, $€ \cdot \mathrm{kg}^{-1}$

$\mathrm{c}_{\mathrm{Ni}} \quad$ Specific cost of catalyst, $€ \cdot \mathrm{kg}^{-1}$

crefr $\quad$ Cost of refractory, $€ \cdot \mathrm{kg}^{-1}$

$c_{\text {steel }} \quad$ Cost of steel, $€ \cdot \mathrm{kg}^{-1}$

$\mathrm{C}_{0} \quad$ Reference cost of high-temperature valve, $€$

$\mathrm{C}_{\text {aux }} \quad$ Capital cost of fuel cell auxiliaries, $€$

Cburn $\quad$ Capital cost of burner, $€$

$\mathrm{C}_{\text {cond }} \quad$ Capital cost of condenser, $€$

CF Capacity Factor

$\mathrm{C}_{\text {inv }} \quad$ Capital cost of inverter, $€$

$\mathrm{C}_{\text {net }} \quad$ Capital cost of reactor network, $€$

$\mathrm{C}_{\mathrm{pb}} \quad$ Capital cost of fixed reactor, $€ \cdot \mathrm{Nr}^{-1}$

$\mathrm{C}_{\text {sol }} \quad$ Capital cost of solid material (sorbent and catalyst), $€ \cdot \mathrm{Nr}^{-1}$

CsofC Capital cost of fuel cell system, $€$

$\mathrm{C}_{\text {stack }} \quad$ Capital cost of fuel cell stack, $€$

CT Carbon tax, $€ \cdot$ tco $^{-1}$

CTS $\quad \mathrm{CO}_{2}$ transport and storage cost, $€ \cdot \mathrm{tCO}^{-1}$

$\mathrm{C}_{\mathrm{v}} \quad$ Capital cost of high-temperature valve, $€ \cdot \mathrm{Nr}^{-1}$

$\mathrm{C}_{\mathrm{vp}} \quad$ Capital cost of vacuum pump, $€ \cdot \mathrm{Nr}^{-1}$

d Internal diameter of the reactor, $\mathrm{m}$

$d_{a} \quad$ Diameter of the refractory and the reactor, $m$

$\mathrm{d}_{\text {cell }} \quad$ Diameter of cell, $\mathrm{m}$

$\mathrm{d}_{\text {cond }} \quad$ Condenser tube outer diameter, $\mathrm{m}$

$\mathrm{d}_{\text {cond, } \mathrm{i}} \quad$ Condenser tube inner diameter, $\mathrm{m}$

DP Daily profit, $€$

ecO2 Specific $\mathrm{CO}_{2}$ emission, $\mathrm{tCO}_{2} \cdot \mathrm{kWh}^{-1}$

$\mathrm{E}_{\mathrm{H} 2} \quad$ Power available from $\mathrm{H}_{2}, \mathrm{~kW}$ 


\begin{tabular}{|c|c|}
\hline $\mathrm{E}_{\mathrm{j}}$ & $\mathrm{E}_{\text {cell }}$ or $\mathrm{E}_{\text {net }}$ in Eq. (19), $\mathrm{kW}_{\mathrm{el}}$ \\
\hline$E_{\text {net }}$ & Net power production of SE-SMR-SOFC system, $\mathrm{kW}_{\mathrm{el}}$ \\
\hline EsOFC & SOFC output power, $\mathrm{kW}$ el \\
\hline $\mathrm{f}$ & Design stress of carbon steel, $\mathrm{Pa}$ \\
\hline FCF & Fixed Charge Factor \\
\hline FOM & Fixed Operating and Maintenance Costs, $€$ \\
\hline $\mathrm{K}_{\mathrm{j}}$ & CTS or CT in Eq. (19), € \\
\hline $\mathrm{L}$ & Reactor length, $\mathrm{m}$ \\
\hline Lcell & Cell length, m \\
\hline Lcond & Condenser tube length, m \\
\hline LCOE & Levelised cost of energy, $€ \cdot \mathrm{kWh}_{\mathrm{el}}^{-1}$ \\
\hline $\mathrm{LCOH}$ & Levelised cost of hydrogen, $€ \cdot \mathrm{kWh}^{-1}$ \\
\hline $\mathrm{LHV}_{\mathrm{H} 2}$ & Lower Heating Value of $\mathrm{H}_{2}, \mathrm{~kJ} \cdot \mathrm{mol}^{-1}$ \\
\hline $\mathrm{m}_{\mathrm{s}}$ & Mass of solid, kg \\
\hline $\mathrm{n}_{\text {cells }}$ & Number of cells \\
\hline $\mathrm{n}_{\text {cond }}$ & Number of condenser tubes \\
\hline$\dot{\mathrm{n}}_{\mathrm{H}_{2}}$ & Outlet $\mathrm{H}_{2}$ molar flow, $\mathrm{mol} \cdot \mathrm{s}^{-1}$ \\
\hline $\mathrm{Nr}$ & Number of reactors \\
\hline PSE-SMR & Maximum pressure of SE-SMR, Pa \\
\hline $\mathrm{R}$ & Revenue from electricity sales, $€$ \\
\hline Q & Heat losses through reactor wall, W \\
\hline Qburn & Power generated by the burner, $\mathrm{kW}_{\text {th }}$ \\
\hline $\mathrm{r}$ & Project interest rate per annum \\
\hline $\mathrm{Sc}_{\mathrm{c}}$ & Thickness of condenser tube wall, $\mathrm{m}$ \\
\hline $\mathrm{Ss}_{\mathrm{s}}$ & Thickness of steel vessel, $\mathrm{m}$ \\
\hline $\mathrm{Sr}$ & Thickness of refractory, $\mathrm{m}$ \\
\hline SFC & Specific Fuel Cost, $€ \cdot \mathrm{kWh}^{-1}$ \\
\hline tCS & Period of carbonation stage \\
\hline TCR & Total Capital Requirement, $€$ \\
\hline TSE-SMR & Temperature of SE-SMR process, K \\
\hline $\mathrm{T}_{\text {steel }}$ & Maximum temperature of steel, $\mathrm{K}$ \\
\hline$\dot{\mathrm{V}}_{0}$ & Reference flow rate, $\mathrm{m}^{3} \cdot \mathrm{s}^{-1}$ \\
\hline$\dot{\mathrm{V}}$ & Maximum volumetric flow rate during SE-SMR, $\mathrm{m}^{3} \cdot \mathrm{s}^{-1}$ \\
\hline $\mathrm{V}$ & Volume, $\mathrm{m}^{3}$ \\
\hline
\end{tabular}


VOM Variable Operating and Maintenance Costs, $€ \cdot \mathrm{kWh}^{-1}$

Greek letters

$\alpha \quad$ Amortisation, years

$\eta_{\text {net }} \quad$ Net efficiency

$\lambda \quad$ Thermal conductivity of refractory, $\mathrm{W} \cdot \mathrm{m}^{-1} \cdot \mathrm{K}^{-1}$

$\omega \quad$ Mass fraction

Subscripts

NG Natural Gas

PS Proposed System

ref Reference

refr Refractory

S1 SE-SMR system

S2 SE-SMR-SOFC system

steel Steel

Acronyms

CLR Chemical Looping Reforming

NG-PP Natural Gas-fired Power Plant

SE-SMR Sorption-Enhanced Steam Methane Reforming

SMR Steam Methane Reforming

SOFC Solid Oxide Fuel Cell 


\section{Introduction}

Regardless of recent progress on climate change mitigation, major efforts are still needed to decrease anthropogenic greenhouse gas emissions into the atmosphere, of which $\mathrm{CO}_{2}$ emissions are one of the most significant [1]. The energy sector is expected to play a key role to meet the emission reduction targets. In this context, $\mathrm{H}_{2}$ represents a promising route towards decarbonisation of the energy sector. It can be used for power generation, in both the residential/commercial and transportation sectors, as well as a chemical raw material for several industrial processes [2]. However, $\mathrm{H}_{2}$ is a secondary form of energy that has to be produced. Usually, methane is used as feedstock for this purpose, because it is abundant and characterised by a high $\mathrm{H}: \mathrm{C}$ ratio [2].

Steam methane reforming (SMR) is the most used technology, although chemical looping reforming (CLR) has recently been shown to be a competitive alternative. In SMR, methane and water are catalytically reformed in a multi-tubular reactor packed with a Ni-based catalyst [3]. In CLR, a Ni-based oxygen carrier is oxidised by air (oxidation stage) and reduced by methane (reduction stage) in cycles. By feeding water during the reduction stage, the metal oxide acts also as a catalyst for the reforming reactions [4,5]. The main drawback of these processes is the requirement of a gas post-processing unit to obtain pure $\mathrm{H}_{2}$. In fact, the effluent gas of SMR and CLR is syngas, a mixture of $\mathrm{H}_{2}$ and $\mathrm{CO}(\sim 12 \%)$, thus at least one gas shift reactor to convert $\mathrm{CO}$ to $\mathrm{CO}_{2}$ and a $\mathrm{CO}_{2}$ separation unit, usually amine scrubbing or pressure swing adsorption, are needed [6]. These components not only account for about $35 \%$ of the total capital cost of SMR/CLR [7], but they also cause a decrease in the efficiency of the reforming process by 6-10\% [8].

Sorption-enhanced steam methane reforming (SE-SMR) is a promising alternative for $\mathrm{H}_{2}$ production that does not require the gas post-processing unit [9]. In this process, the reactor is filled with a mixture of reforming catalyst and $\mathrm{CO}_{2}$ solid adsorbent, usually $\mathrm{CaO}$, and the process is carried out in two distinct stages, namely carbonation and calcination [10]. During the first stage, by feeding a mixture of methane and water, reforming reactions and $\mathrm{CO}_{2}$ adsorption via $\mathrm{CaO}$ carbonation take place, producing a high-purity $\mathrm{H}_{2}$ stream $\left(y_{H_{2}}>90 \%\right)$. During the second stage, the sorbent material is regenerated via the calcination reaction, which is the reverse of carbonation, producing a stream of concentrated $\mathrm{CO}_{2}$. Over the past years, this process has been extensively studied in a dual fluidised bed arrangement, one reactor acting as carbonator and the other as calciner $[11,12]$. Recently, the packed bed reactor has received a great deal of attention because, as opposed to fluidsed bed reactors, this arrangement requires no gas/solid separation step, and of its ability to easily operate under pressure $[13,14]$. The SE-SMR process in fixed beds has been studied from both the experimental and numerical points of view. Li et al. [15] conducted an experimental campaign in a laboratory-scale 
apparatus consisting of two parallel fixed beds placed inside an electric furnace, alternately operated as carbonator and calciner. The authors claimed that the operating conditions and feed switchover time are the critical parameters for achieving a high concentration of produced $\mathrm{H}_{2}$. Antzara et al. [16] experimentally demonstrated high-purity $\mathrm{H}_{2}$ generation ( 95\%) in a laboratory-scale fixed bed reactor filled with a $\mathrm{ZrO}_{2}$-promoted $\mathrm{CaO}$ sorbent and $\mathrm{Ni} / \mathrm{NiO}$ oxygen carrier. In this configuration, exothermic oxidation of the oxygen carrier supplies heat required by endothermic calcination. Fernandez et al. [17] developed a mathematical model to investigate the carbonation stage of SESMR in a pressurised autothermal packed bed, obtaining a hydrogen purity of $\sim 95 \%$ at operating pressure of 3.5 MPa. Li and Cai [18] numerically analysed the performance of SE-SMR operated in a single packed bed alternating calcination and carbonation steps.

Review of the literature has demonstrated that further research on SE-SMR in fixed beds is still needed, since the current studies have been focused only on small-scale reactors. In order to promote the scale-up of this technology, Diglio et al. [19] recently numerically investigated the SE-SMR process in a large-scale fixed bed reactor system. Considering isothermal conditions (973 K), the equilibrium between the carbonation and calcination stages was shifted by a pressure swing: $3.5 \mathrm{MPa}$ and $1013 \mathrm{~Pa}$, respectively. The authors assessed that under these operating conditions 8 reactors in parallel are required to continuously produce a high-purity $\mathrm{H}_{2}$ stream (92\%). Moreover, they claimed that by using a portion of the produced $\mathrm{H}_{2}$, it is possible to make the process self-sufficient from the point of view of energy consumption. Since this arrangement showed high performance in terms of $\mathrm{H}_{2}$ yield (2.9 mol $_{2} \cdot \mathrm{mol}_{\mathrm{CH}^{-1}}{ }^{-1}$ ) and reforming efficiency (80\%), a rigorous techno-economic analysis is the necessary successive step towards the employment of this novel solution.

The aim of this work is to assess the techno-economic feasibility of the SE-SMR process operated in a network of fixed bed reactors. The performance of such arrangement is benchmarked against conventional SMR and CLR. Moreover, to take into account the uncertainly due to market effects, the influence of the capital cost of the main components of the system on the levelised cost of energy and cost of $\mathrm{CO}_{2}$ avoided was investigated. In addition, since the coupling between $\mathrm{H}_{2}$ and fuel cell technologies can support climate change goals in the energy sector [20], the economic feasibility of integration of the proposed $\mathrm{H}_{2}$ production system with a solid oxide fuel cell (SOFC) was quantified. The comparison with a conventional natural gas-fired power plant was also performed. A detailed sensitivity analysis was undertaken in order to evaluate the effect of the capital costs of the system's components on the economic performance indicators. Finally, to account for the variability in the future economic climate, the effects of the variation in carbon tax and carbon transport and storage costs on the daily profit of both the proposed and reference power generation systems were evaluated. 


\section{System Description}

The proposed systems are described in detail in Diglio et al. [19]. Figure 1 shows the schematic layout of the processes. Two different systems are considered, namely SE-SMR and the integrated option with a solid oxide fuel cell (SE-SMR-SOFC). The former is designed for $\mathrm{H}_{2}$ production with inherent $\mathrm{CO}_{2}$ capture, and the latter for power generation.

SE-SMR comprises a network of 8 packed beds operated under the conditions reported by Diglio et al. [19]. The packed beds are filled with a mix of Ni-based catalyst and CaO sorbent, and continuously produce two gas streams, specifically a mixture of $\mathrm{H}_{2} \mathrm{O}$ and $\mathrm{CO}_{2}$, and high-purity $\mathrm{H}_{2}$ $\left(y_{H 2} \sim 92 \%\right)$. The first stream is sent to a condenser to obtain pure $\mathrm{CO}_{2}$, while part of the second is fed to a burner to cover energy demands of the SE-SMR process. The remaining $\mathrm{H}_{2}$ represents the primary product of SE-SMR.

In the case of integration between SE-SMR and SOFC, part of the $\mathrm{H}_{2}$ produced by the SE-SMR process is fed for power generation to the SOFC, consisting of an internally reforming solid fuel cell, since some unreacted $\mathrm{CH}_{4}\left(y_{C H 4} \sim 8 \%\right)$ is present in the outlet gas stream of the SE-SMR process. With the aim of making this process self-sufficient from a thermal point of view, some of the produced $\mathrm{H}_{2}$ is fed directly to an external burner, together with unreacted $\mathrm{H}_{2}$ from the fuel cell. The partition ratio $\imath$ ensures that the heat generated by the burner and available from the SOFC meets the heat demands of both the SE-SMR and the SOFC internal reforming process. The fuel cell power generation, net of electricity demand of the SE-SMR mainly due to vacuum pumps used to carry out sorbent regeneration, is the main product of SE-SMR-SOFC.

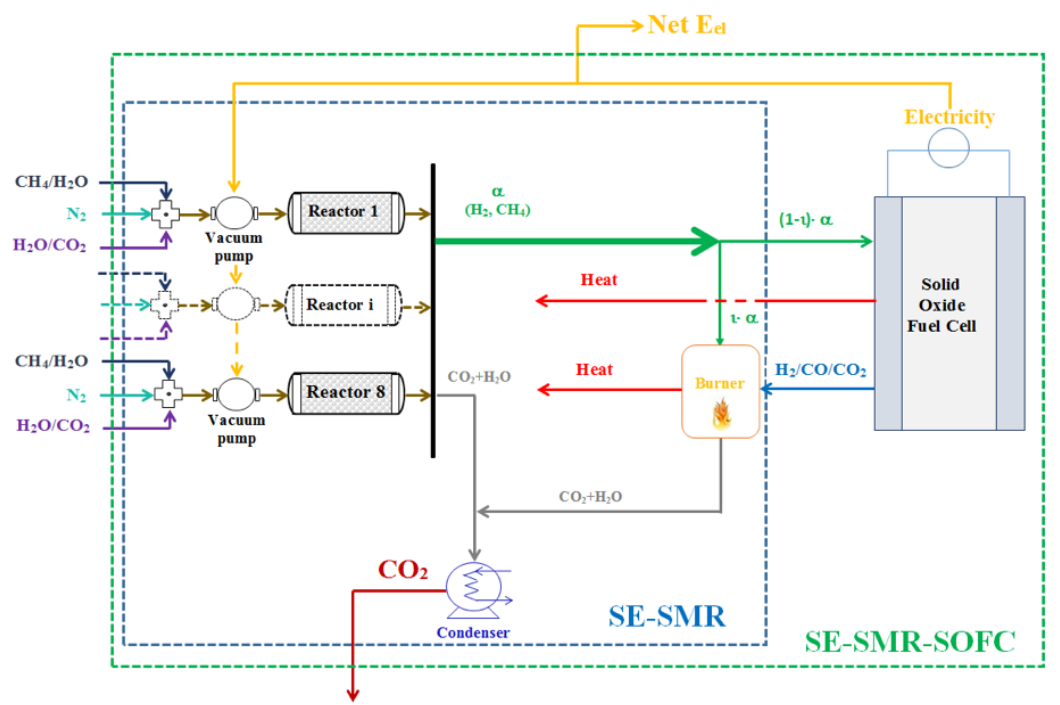

Figure 1 - Layout of the proposed systems. 


\subsection{Thermodynamic performance}

The $\mathrm{H}_{2}$ yield of the SE-SMR system is $2.9 \mathrm{molH}_{2} \cdot \mathrm{molch}^{-1}$, which decreases to 2.5 molH2 $_{2} \cdot$ mol $_{\mathrm{CH}_{4}}{ }^{-1}$ (equivalent $\mathrm{H}_{2}$ yield) when part of the $\mathrm{H}_{2}$ produced is used to supply all heat (the power generated by the external burner is $1.08 \mathrm{MW}$ th) and power demands of the process in order to make it energy self-sufficient. This means that the power available from produced $\mathrm{H}_{2}$ is $1500 \mathrm{~kW}$ $\left(E_{H 2}\right)$. The net efficiency of SE-SMR, i.e., the ratio between the lower heating values of $\mathrm{H}_{2}$ and $\mathrm{CH}_{4}$ multiplied by equivalent $\mathrm{H}_{2}$ yield, is $80 \%$.

In the case of integration of the proposed $\mathrm{H}_{2}$ production system with SOFC, the fuel cell power production $\left(E_{S O F C}\right)$ is $1235 \mathrm{~kW}_{\mathrm{el}}$. By using part of this energy to cover electric energy demand of the SE-SMR, the net power production of SE-SMR-SOFC $\left(E_{n e t}\right)$ is $950 \mathrm{~kW}$ el. Accounting for the $\mathrm{CH}_{4}$ fed to the SE-SMR process, the net efficiency of the SE-SMR-SOFC is $51 \%$.

Table 1 summarises the thermodynamic performance of both SE-SMR and SE-SMR-SOFC, and also reports the operating conditions of the SE-SMR process in terms of maximum volumetric flow rate $(\dot{V})$, temperature $\left(T_{S E-S M R}\right)$, maximum pressure $\left(P_{S E-S M R}\right)$, mass of the solid in the fixed bed $\left(m_{s}\right)$ and mass fraction of sorbent $\left(\omega_{\mathrm{CaO}}\right)$ and nickel $\left(\omega_{N i}\right)$ in the solid [19]. 


\section{Operating parameters}

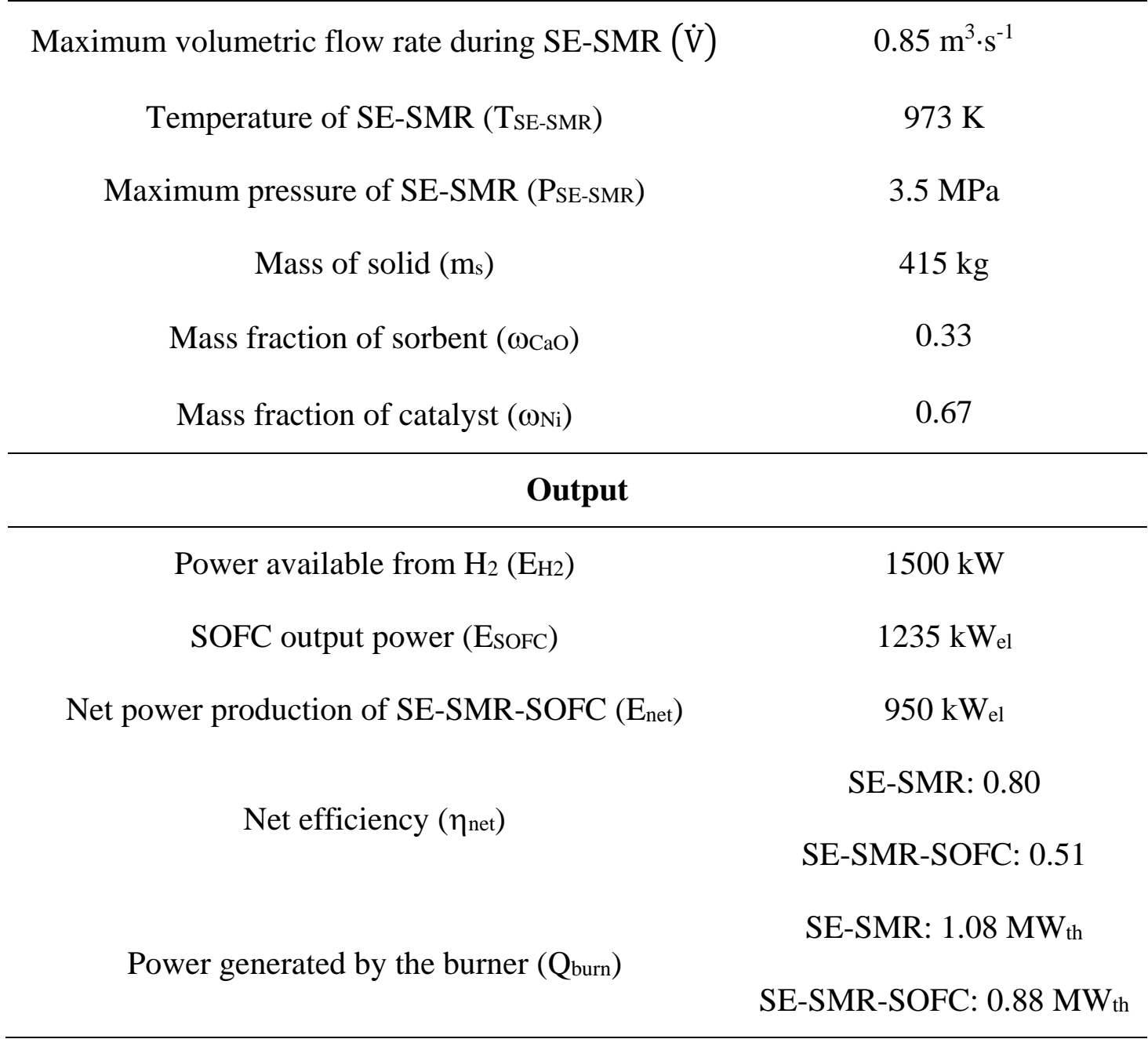

\section{Economic Analysis}

In the following analysis, the economic performance of the two proposed systems (SE-SMR $\left(\mathrm{s}_{1}\right)$ and SE-SMR-SOFC $\left(\mathrm{s}_{2}\right)$ ) has been compared with reference systems without $\mathrm{CO}_{2}$ capture. In particular, the reference system for the former is steam methane reforming (SMR), and an existing natural gas-fired power plant (NG-PP) for the latter. The economic indices used in this analysis are the levelised cost of hydrogen $(\mathrm{LCOH})$ for SE-SMR, the levelised cost of energy $(L C O E)$ for the SESMR-SOFC and the cost of $\mathrm{CO}_{2}$ avoided $(A C)$ for both [21]:

$$
L C O H=\frac{T C R_{S_{1}} \cdot F C F+F O M_{S_{1}}}{C F \cdot E_{H_{2}} \cdot 8760}+V O M_{S_{1}}+\frac{S F C_{C H_{4}}}{\eta_{n e t_{S_{1}}}}
$$




$$
\begin{aligned}
& L C O E_{j}=\frac{T C R_{j} \cdot F C F+F O M_{j}}{C F \cdot E_{n e t} \cdot 8760}+V O M_{j}+\frac{S F C_{j}}{\eta_{n e t, j}} \quad j=s_{2}, \text { ref } \\
& A C_{i}=\frac{I N_{P S}-I N_{r e f}}{e_{C O_{2}, r e f, i}-e_{C O_{2}, P S}} \quad i=s_{1}, s_{2}
\end{aligned}
$$

where $\mathrm{CH}_{4}$ and natural gas are the fuel for SE-SMR-SOFC and natural gas-fired power plant, respectively; IN is $L C O H$ in the case of SE-SMR, $L C O E$ in the case of SE-SMR-SOFC. $E_{H 2}$ represents the average power available from net $\mathrm{H}_{2}$ production of SE-SMR, while $E_{n e t}$ is the power generation of SOFC, net of electricity demand of SE-SMR. The fixed operating and maintenance costs $(F O M)$ were assumed to be $1 \%$ of total capital requirement $(T C R)$ for both reference and proposed systems, respectively [21]. Moreover, the variable operating and maintenance costs (VOM) were considered equal to $2 \%$ and $4 \%$ of $T C R$ for proposed [21] and reference systems, respectively.

The fixed charge factor $(F C F)$ was evaluated as [22]:

$$
F C F=\frac{r}{1-(r+1)^{\alpha}}
$$

It was considered that the project interest rate $(r)$ and amortisation years $(\alpha)$ are $8.78 \%$ and 25 , respectively [21], for both proposed systems, as well as for the reference ones.

The total capital requirement for the systems under investigation has been calculated as:

$$
\begin{aligned}
& T C R_{s_{1}}=C_{n e t}+C_{\text {burn } s_{1}}+C_{\text {cond }} \\
& T C R_{s_{2}}=C_{n e t}+C_{S O F C}+C_{\text {burn },_{2}}+C_{\text {cond }}
\end{aligned}
$$

All parameters used for the economic analysis have been reported in Table 2. Since both SESMR and SE-SMR-SOFC are near-zero $\mathrm{CO}_{2}$ emission processes [19], eCO2,PS is assumed to be 0 in both cases. 
Table 2 - Parameters used to evaluate economic performance.

\begin{tabular}{|c|c|c|}
\hline Parameter & Value & Reference \\
\hline $\mathrm{C}_{0}$ & $150000 €$ & [23] \\
\hline Specific cost of steel ( $\left.\mathrm{c}_{\text {steel }}\right)$ & $0.50 € \cdot \mathrm{kg}^{-1}$ & [23] \\
\hline Specific cost of refractory $\left(c_{\text {refr }}\right)$ & $0.45 € \cdot \mathrm{kg}^{-1}$ & {$[23]$} \\
\hline Specific cost of sorbent $(\mathrm{c} \mathrm{CaO})$ & $0.02 € \cdot \mathrm{kg}^{-1}$ & {$[24]$} \\
\hline Specific cost of catalyst $\left(\mathrm{c}_{\mathrm{Ni}}\right)$ & $50 € \cdot \mathrm{kg}^{-1}$ & [23] \\
\hline Specific cost of vacuum pump $\left(\mathrm{C}_{\mathrm{vp}}\right)$ & $4000 €$ & {$[25]$} \\
\hline Specific cost of burner $(\mathrm{cbb})$ & $360 € \cdot \mathrm{kW}_{\text {th }}$ & {$[26]$} \\
\hline Specific cost of condenser $\left(\mathrm{c}_{\mathrm{cc}}\right)$ & $241 € \cdot \mathrm{m}^{-2}$ & {$[27]$} \\
\hline $\mathrm{CO}_{2}$ transport and storage cost (CTS) & $7 € \cdot \mathrm{tCO}^{-1}$ & {$[21]$} \\
\hline Carbon tax (CT) & $18 € \cdot \mathrm{tcO}^{-1}$ & {$[21]$} \\
\hline Capacity factor $(\mathrm{CF})$ & $\begin{array}{c}\text { SE-SMR: } 0.80 \\
\text { SE-SMR-SOFC: } 0.97\end{array}$ & $\begin{array}{l}{[21]} \\
{[28]}\end{array}$ \\
\hline Specific cost of power plant $\left(c_{\text {ref }}\right)$ & $700 € \cdot \mathrm{kWh}^{-1}$ & {$[29]$} \\
\hline Total capital requirement power plant $\left(\mathrm{TCR}_{\mathrm{ref}}\right)$ & $c_{\text {reff }} \cdot E_{n e t}$ & - \\
\hline Net efficiency power plant ( $\left.\eta_{\text {net,ref }}\right)$ & 0.55 & {$[29]$} \\
\hline Specific cost $\mathrm{CH}_{4}\left(\mathrm{SFC}_{\mathrm{CH}} 4\right)$ & $0.019 € \cdot \mathrm{kWh}^{-1}$ & {$[29]$} \\
\hline Specific cost natural gas $\left(\mathrm{SFC}_{\mathrm{NG}}\right)$ & $0.013 € \cdot \mathrm{kWh}^{-1}$ & {$[29]$} \\
\hline $\mathrm{CO}_{2}$ emission power plant (eco2,ref,s1) & $0.62 \mathrm{tCO} 2 \cdot \mathrm{MWh}^{-1}$ & {$[21]$} \\
\hline $\mathrm{CO}_{2}$ emission $\mathrm{SMR}\left(\mathrm{e}_{\mathrm{CO} 2, \mathrm{ref}, \mathrm{s} 2}\right)$ & $0.97 \mathrm{tCO} 2_{\mathrm{CO}} \cdot \mathrm{MWh}^{-1}$ & [29] \\
\hline
\end{tabular}

\subsection{Reactor network cost analysis}

The cost of the reactor network was expressed as [30]:

$$
C_{n e t}=N r \cdot\left(C_{v}+C_{p b}+C_{s o l}+C_{v p}\right)
$$

The reference cost of the high-temperature valve $\left(\mathrm{C}_{0}\right)$ includes also the high-temperature piping [30]. In the case of flow rates varying from that of the reference $\left(\dot{V}_{0}=2 \mathrm{~m}^{3} \cdot \mathrm{s}^{-1}\right)$, the cost has been scaled according to the following equation [30]:

$$
C_{v}=C_{0}\left(\frac{\dot{V}}{\dot{V}_{0}}\right)^{0.6}
$$


To assess the reactor cost $\left(C_{p b}\right)$ it is necessary to account for the cost of both refractory and steel. In fact, the reactor is made up of an internal refractory, a steel vessel and an external refractory. The refractory is needed to protect the steel vessel at the highest temperature reached during the process. The thickness of the steel vessel $\left(s_{s}\right)$ was calculated based on the energy balance on the insulation material around the reactor wall and Fourier's law [30], as presented in Eqs (9) and (10), while the thickness of refractory $\left(s_{r}\right)$ was assessed considering a $s_{s} / s_{r}$ ratio of 0.1 [30].

$$
\begin{aligned}
& Q=\frac{2 \pi \lambda L}{\ln \left(d_{a} / d\right)}\left(T_{S E-S M R}-T_{\text {steel }}\right) \\
& S_{S}=\frac{P_{S E-S M R} d_{a}}{4 f-1.2 P_{C S}}
\end{aligned}
$$

where the maximum temperature of the steel $\left(T_{\text {steel }}\right)$ is fixed at $573 \mathrm{~K}$ [30]. The thermal conductivity of refractory $(\lambda)$ is $0.2 \mathrm{~W} \cdot \mathrm{m}^{-1} \cdot \mathrm{K}^{-1}[30]$ and $f$ is $85 \mathrm{~Pa}[30]$.

The cost of the reactor was evaluated as:

$$
C_{p b}=V_{\text {steel }} \cdot \rho_{\text {steel }} \cdot c_{\text {steel }}+V_{\text {refr }} \cdot \rho_{\text {refr }} \cdot c_{\text {refr }}
$$

where the density of steel $\left(\rho_{\text {steel }}\right)$ is $7850 \mathrm{~kg} \cdot \mathrm{m}^{-3}$ [31], while that of refractory $\left(\rho_{\text {refr }}\right)$ is $480 \mathrm{~kg} \cdot \mathrm{m}^{-3}[30]$.

The cost of solid material was evaluated as:

$$
C_{\text {Sol }}=c_{C a O} \cdot m_{S} \cdot \omega_{C a O}+c_{N i} \cdot m_{S} \cdot \omega_{N i}
$$

\subsection{SOFC cost analysis}

Following the approach adopted by Arsalis [27], the cost of the SOFC was evaluated as:

$$
C_{\text {SOFC }}=C_{\text {stack }}+C_{\text {inv }}+C_{\text {aux }}
$$

where $C_{\text {stack }}$ represents the cost of the SOFC stack, $C_{i n v}$ the cost of the inverter and $C_{\text {aux }}$ the cost of the auxiliaries, such as internal reformer, mixers and by-pass valves. This latter was considered to be $5 \%$ of the stack cost [27]. 
The cost of the fuel cell stack was estimated according to the active area and the operating temperature of the SOFC, while that for the inverter was calculated by taking into account the power generated by the fuel cell [27]:

$$
\begin{aligned}
& C_{\text {stack }}=\left(n_{\text {cells }} \pi d_{\text {cell }} L_{\text {cell }}\right)\left(2.96 T_{S E-S M R}-1907\right) \\
& C_{i n v}=10^{5}\left(\frac{E_{S O F C}}{500}\right)^{0.70}
\end{aligned}
$$

The parameters used for the SOFC economic analysis are reported in Table 3 and were determined based on literature data [27].

Table 3 - Parameters used for SOFC economic analysis.

\begin{tabular}{ccc}
\hline Parameter & Value & Reference \\
\hline $\mathrm{n}_{\text {cells }}$ & 65000 & {$[27]$} \\
$\mathrm{d}_{\text {cell }}$ & $0.0156 \mathrm{~m}$ & {$[27]$} \\
$\mathrm{L}_{\text {cell }}$ & $1.5 \mathrm{~m}$ & {$[27]$} \\
\hline
\end{tabular}

\subsection{Burner and condenser cost analysis}

The cost of burner was assessed according to thermal power produced:

$$
C_{\text {burn }}=Q_{\text {burn }} \cdot c_{b b}
$$

The condenser is a shell-and-tube heat exchanger and its cost was assessed by considering the required heat transfer area [27]:

$$
\begin{aligned}
& C_{\text {cond }}=A_{\text {cond }} \cdot c_{c c} \\
& A_{\text {cond }}=n_{\text {cond }} \pi d_{\text {cond }} L_{\text {cond }}
\end{aligned}
$$

The parameters reported in Table 4 for evaluating the cost of the condenser are assumed from the literature [27], taking into account the steam pressure and mass flow rate. 
Table 4 - Parameters used to evaluate the cost of condenser.

\begin{tabular}{ccc}
\hline Parameter & Value & Reference \\
\hline $\mathrm{n}_{\text {cond }}$ & 50 & {$[27]$} \\
$\mathrm{d}_{\text {cond,i }}$ & $0.02 \mathrm{~m}$ & {$[27]$} \\
$\mathrm{sc}_{\mathrm{c}}$ & $0.005 \mathrm{~m}$ & {$[27]$} \\
$\mathrm{d}_{\text {cond }}$ & $d_{\text {cond }, i}+2 s_{c}$ & - \\
$\mathrm{L}_{\text {cond }}$ & $6.7 \mathrm{~m}$ & {$[27]$} \\
\hline
\end{tabular}

\section{Results and Discussion}

In the following, the economic performance of SE-SMR and SE-SMR-SOFC were evaluated with economic parameters reported in Table 2 (base case). Moreover, a sensitivity analysis was carried out, by varying the specific costs of burner, refractory, steel, fuel, catalyst and sorbent and the total cost of SOFC by $\pm 10 \%$.

\subsection{Economic performance of SE-SMR - Base case}

Figure 2 shows the contribution of each component (see Table 5 for the detailed costs) to the total cost of the SE-SMR. The reactor network represents the most expensive part of SE-SMR, with a specific cost of investment of $620 € \cdot \mathrm{kW}^{-1}$, which is in good agreement with literature data [30]. This means that the operating conditions of SE-SMR should be carefully chosen, in order to decrease the number of reactors $\left(N_{r}\right)$ required and, consequently, to reduce the total capital cost of the system. In particular, the total period of the process is the main parameter that affects $N_{r}$ : since the period of the calcination stage is strictly linked to the complete regeneration of the sorbent; only the period of the carbonation stage $\left(t_{C S}\right)$ can be tailored for such scope. This period should represent a compromise between two opposite effects: on the one hand, small $t_{C S}$ is required to reach high-purity $\mathrm{H}_{2}$ production; on the other hand, high $t_{C S}$ is needed to decrease $\mathrm{N}_{\mathrm{r}}$. The most expensive component of reactor network is the high-temperature valve. This was expected, since, due to the presence of cheap sorbent $\left(\mathrm{CaCO}_{3}\right)$, the impact of the solid material is not as significant as in similar reforming applications [23] in which only highly expensive Ni catalyst is used. 


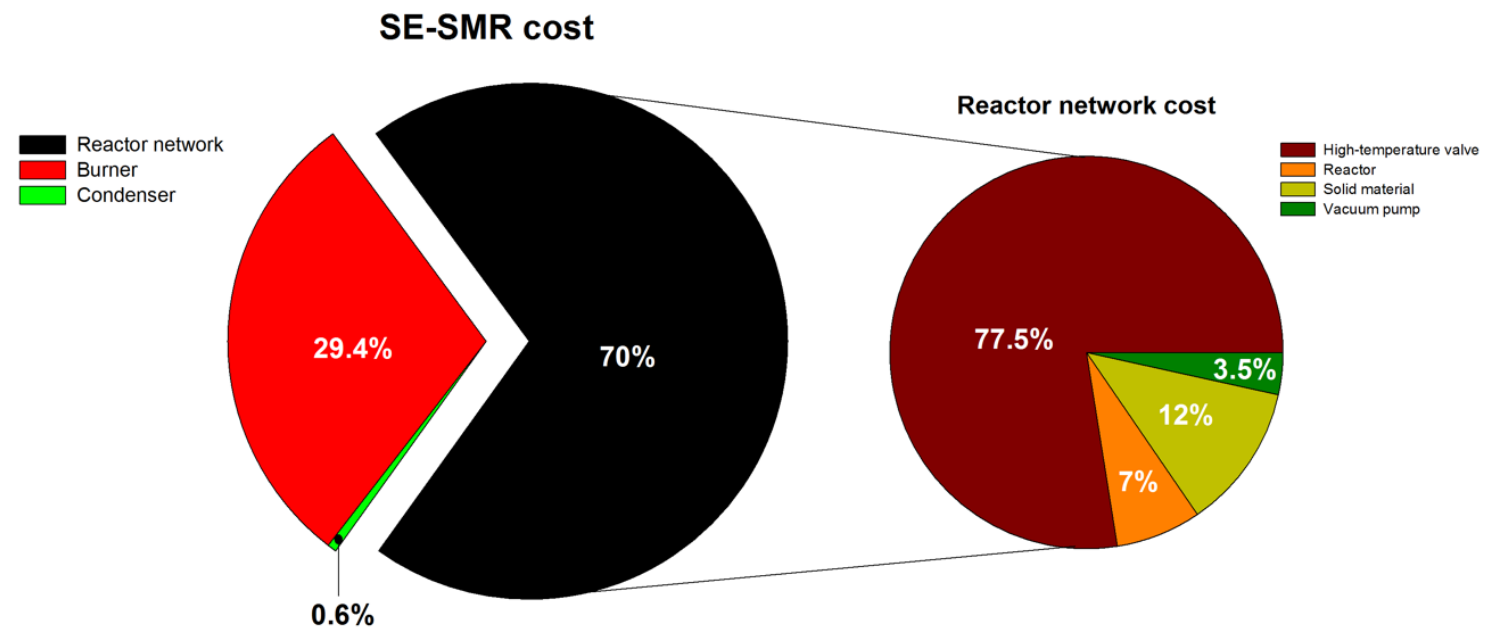

Figure 2 - Relative cost of SE-SMR components.

Table 5 - Detailed costs of SE-SMR.

\begin{tabular}{|c|c|}
\hline \multicolumn{2}{|l|}{ SE-SMR process } \\
\hline Parameter & Value \\
\hline Cost of high-temperature valve $\left(\mathrm{C}_{\mathrm{v}}\right)$ & $89769 € \cdot \mathrm{Nr}^{-1}$ \\
\hline Cost of reactor $\left(\mathrm{C}_{\mathrm{pb}}\right)$ & $8147 € \cdot \mathrm{Nr}^{-1}$ \\
\hline Cost of solid $\left(\mathrm{C}_{\mathrm{sol}}\right)$ & $13905 € \cdot \mathrm{Nr}^{-1}$ \\
\hline Cost of vacuum pump $\left(\mathrm{C}_{\mathrm{vp}}\right)$ & $4000 € \cdot \mathrm{Nr}^{-1}$ \\
\hline Cost of reactor network $\left(\mathrm{C}_{\text {net }}\right)$ & $0.93 \mathrm{M} €$ \\
\hline Cost of burner (Cburn,s1) & $0.39 \mathrm{M} €$ \\
\hline Cost of condenser $\left(\mathrm{C}_{\text {cond }}\right)$ & $7605 €$ \\
\hline Total capital requirement $\left(\mathrm{TCR}_{\mathrm{s} 1}\right)$ & $1.32 \mathrm{M} €$ \\
\hline Levelised cost of $\mathrm{H}_{2} \mathrm{SMR}\left(\mathrm{LCOH}_{\mathrm{ref}}\right)$ & $0.03 € \cdot \mathrm{kWh}_{\mathrm{el}}{ }^{-1}$ \\
\hline Levelised cost of $\mathrm{H}_{2}(\mathrm{LCOH})$ & $0.049 € \cdot \mathrm{kWh}^{-1}$ \\
\hline Cost of $\mathrm{CO}_{2}$ avoided $\left(\mathrm{AC}_{\mathrm{s} 1}\right)$ & $29.85 € \cdot \mathrm{tCO}^{-1}$ \\
\hline
\end{tabular}

The cost of hydrogen for the SMR process without $\mathrm{CO}_{2}$ capture $\left(\mathrm{LCOH}_{\text {ref }}\right)$ reported in Table 5 was evaluated from [29]. The results in Table 5 show that the proposed system is highly competitive in comparison with the conventional system used for $\mathrm{H}_{2}$ production. Considering the LHV, the cost of produced $\mathrm{H}_{2}$ is $1.6 € \cdot \mathrm{kg}^{-1}$, while for the $\mathrm{SMR}$ with $\mathrm{CO}_{2}$ capture system, consisting of monoethanolamine solvent to absorb $\mathrm{CO}_{2}$ from the outlet gas mixture, is about $2.4 € \cdot \mathrm{kg}^{-1}$ [32] and for 
CLR technologies it is between $1.7-2 € \cdot \mathrm{kg}^{-1}$ [32]. Also the estimated cost of $\mathrm{CO}_{2}$ avoided (29.85 $\left.€ \cdot \mathrm{tCO}^{-1}\right)$ is significantly lower when compared to the cases of $\mathrm{SMR}$ with $\mathrm{CO}_{2}$ capture (50 € $\cdot \mathrm{tCO}^{-1}$ [29]) and CLR $\left(85 € \cdot \mathrm{tCO}^{-1}[33]\right)$.

\subsection{Economic performance of SE-SMR - Sensitivity analysis}

Figure 3a presents the results of the sensitivity analysis for $\mathrm{LCOH}$, while Figure $3 \mathrm{~b}$ is for AC. The price of fuel has the strongest impact on both $\mathrm{LCOH}(-7.5 \%$ to $7 \%)$ and AC (-19\% to $16 \%)$; among all investigated parameters, it is the most uncertain and market dependent. The burner is the second most expensive component of SE-SMR (see Figure 2) thus, after the fuel, it has the largest influence on $\mathrm{LCOH}(-8 \%$ to $8 \%)$ and $\mathrm{AC}(-2 \%$ to $2 \%)$. The contribution of solid material and reactor cost on the total cost is only $7 \%$ and $12 \%$, respectively, as shown in Figure 2, thus their effect on $\mathrm{LCOH}$ and $\mathrm{AC}$ is relatively low. Since the sorbent is very cheap, the variation of its cost has a negligible influence on the cost of hydrogen and $\mathrm{CO}_{2}$ avoided (in both cases $\pm 0.02 \%$ ). 
a)

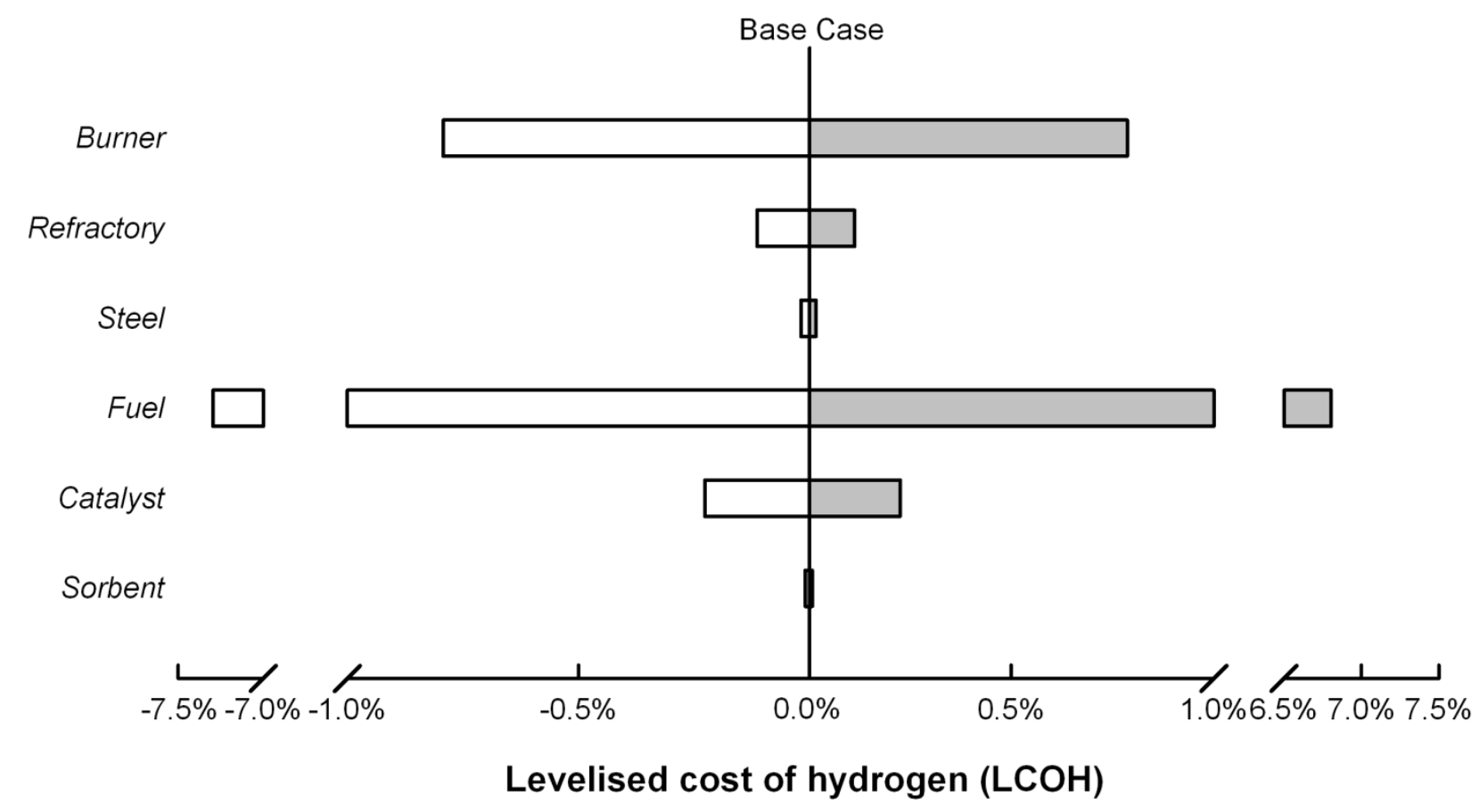

$\square-10 \% \square+10 \%$

b)

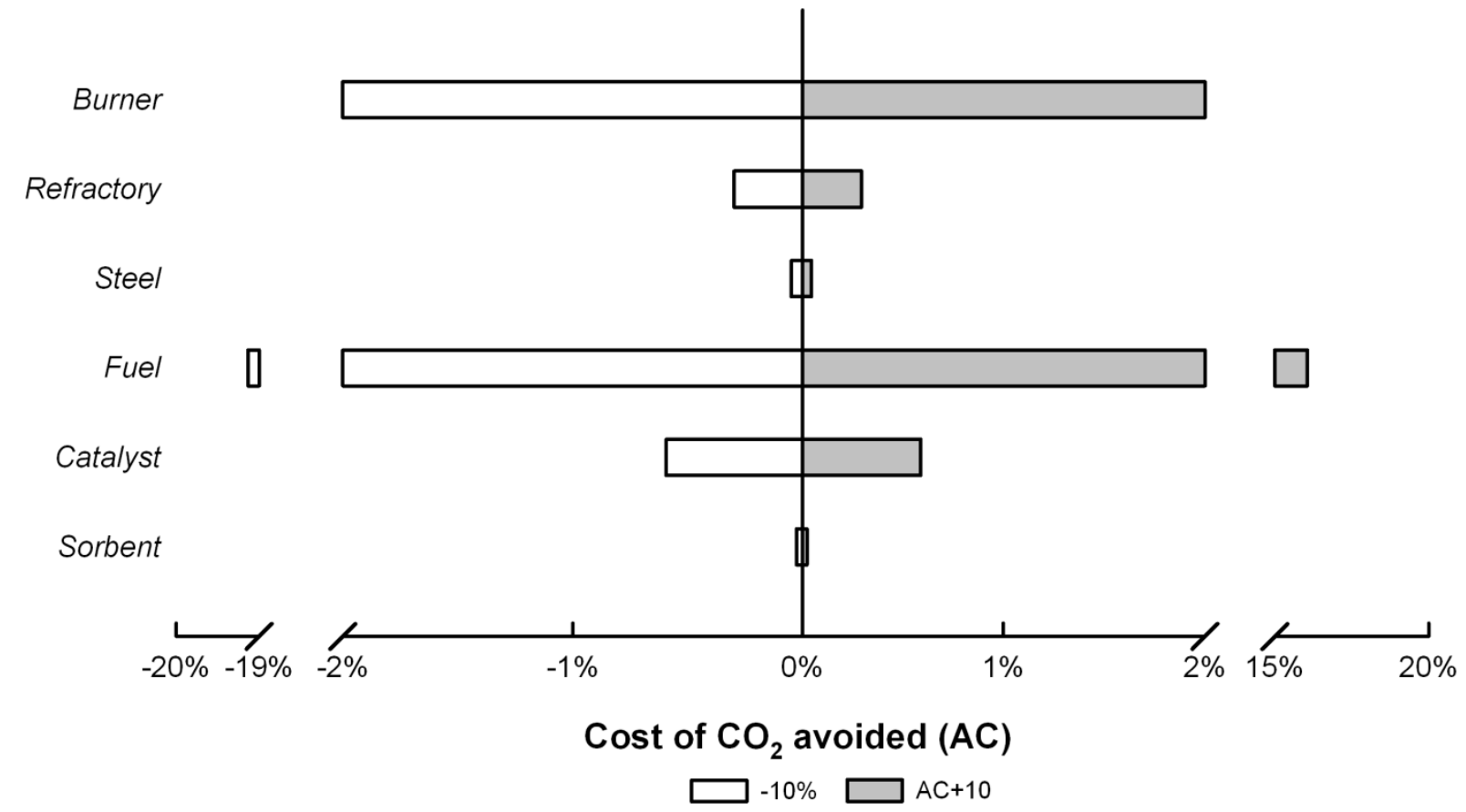

Figure $3-\mathrm{LCOH}(a)$ and AC SE-SMR (b) sensitivity analysis. 


\section{3 - Economic performance of SE-SMR-SOFC system - Base case}

Figure 4 shows the contribution of the main components (see Table 6 for the detailed costs) on the total cost of SE-SMR-SOFC. In this case, the SOFC is the most expensive component, with a specific cost of investment of about $4000 € \cdot \mathrm{kW}^{-1}$, which is in accordance with data reported by Velumani et al. [34] and Facci et al. [35]. It is noteworthy that the cost of the reactor network represents only $14.7 \%$ in this case, while it was the most expensive component of SE-SMR. Thus, the total capital cost in this case is not as dependent on the operating conditions of SE-SMR, i.e., on the number of reactors $\left(N_{r}\right)$. As in the previous case, the contribution of the condenser is negligible to the total capital requirement.

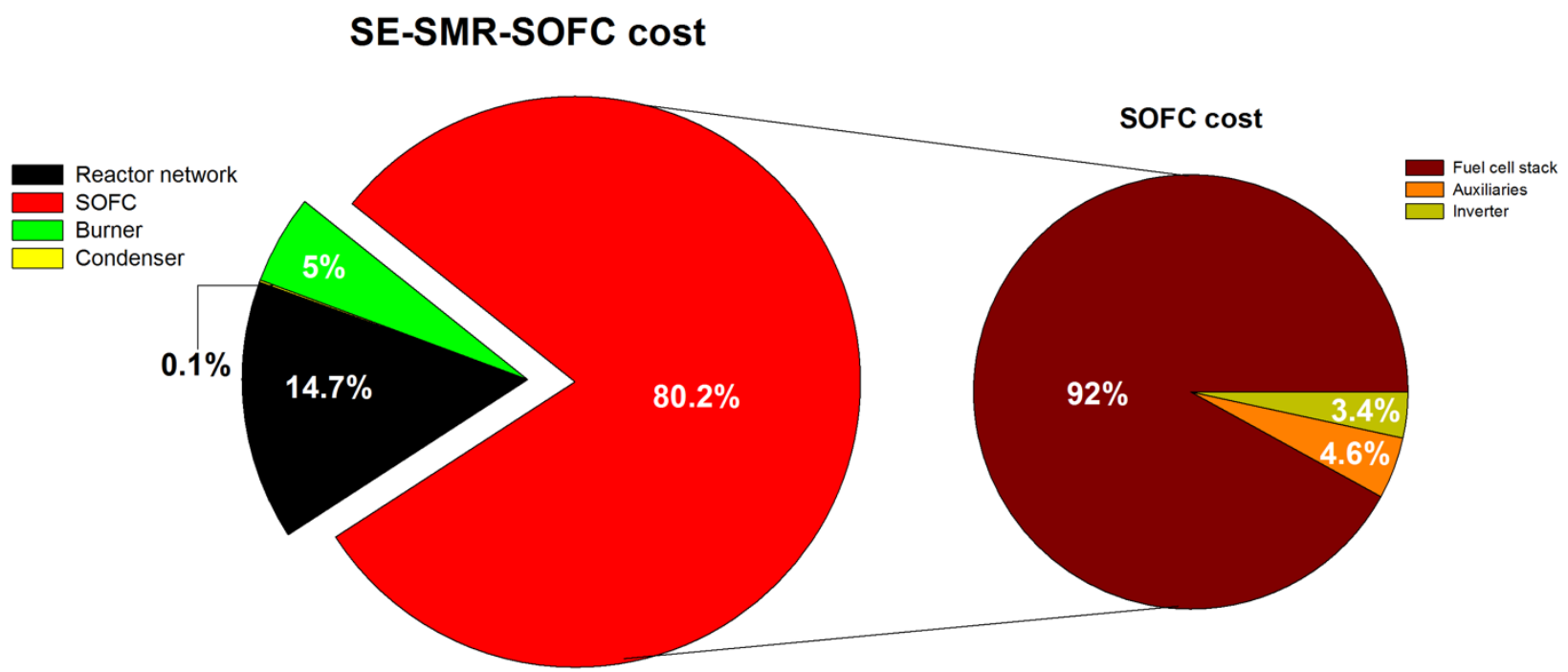

Figure 4-Relative cost of SE-SMR-SOFC components. 
Table 6 - Detailed costs of SE-SMR-SOFC.

TOTAL PLANT (SE-SMR-SOFC)

\begin{tabular}{|c|c|}
\hline Parameter & Value \\
\hline Cost of reactor network $\left(\mathrm{C}_{\text {net }}\right)$ & $0.93 \mathrm{M} €$ \\
\hline Cost of SOFC stack $\left(\mathrm{C}_{\text {stack }}\right)$ & $4.65 \mathrm{M} €$ \\
\hline Cost of SOFC inverter $\left(\mathrm{C}_{\text {inv }}\right)$ & $0.17 \mathrm{M} €$ \\
\hline Cost of SOFC auxiliaries ( $\left.\mathrm{C}_{\text {aux }}\right)$ & $0.23 \mathrm{M} €$ \\
\hline Cost of SOFC (CsofC) & $5.05 \mathrm{M} €$ \\
\hline Cost of burner $\left(\mathrm{C}_{\text {burn,s2 }}\right)$ & $0.32 \mathrm{M} €$ \\
\hline Cost of condenser $\left(\mathrm{C}_{\text {cond }}\right)$ & $7605 €$ \\
\hline Total capital requirement $\left(\mathrm{TCR}_{\mathrm{s} 2}\right)$ & $6.31 \mathrm{M} €$ \\
\hline Levelised cost of energy power plant (LCOE $\mathrm{Lef})$ & $0.042 € \cdot \mathrm{kWh}_{\mathrm{el}}{ }^{-1}$ \\
\hline Levelised cost of energy (LCOE) & $0.078 € \cdot \mathrm{kWhel}^{-1}$ \\
\hline Cost of $\mathrm{CO}_{2}$ avoided $\left(\mathrm{AC}_{\mathrm{s} 2}\right)$ & $36.83 € \cdot \mathrm{tCO}^{-1}$ \\
\hline
\end{tabular}

The levelised cost of energy for the reference system ( $\left.L C O E_{r e f}\right)$ was evaluated according to the parameters shown in Table 2 and is very close to literature data for natural gas-fired power plants [29]. The proposed system has better economic performance than a conventional natural gas-fired power plant with post-combustion capture system, when typically an organic solvent such as monoethanolamine is employed [29], for which LCOE is $\sim 0.080 € \cdot \mathrm{kWh}^{-1}$ and AC is $\sim 80 € \cdot \mathrm{tCO}^{-1}$ [29,36]. As reported by Erans et al. [22,37], a natural gas combined cycle power plant integrated with calcium looping is characterised by $\mathrm{LCOE} \sim 0.044 € \cdot \mathrm{kWh}^{-1}$ and $\mathrm{AC} \sim 30 € \cdot \mathrm{tCO}^{-1}$; thus, with respect to a system using a similar $\mathrm{CO}_{2}$ capture technology, SE-SMR-SOFC has a comparable cost of $\mathrm{CO}_{2}$ avoided, but a higher LCOE, due to integration of the SOFC which worsens the economic performance of proposed system with its high investment cost. However, the capital cost of SOFC is expected to decrease in the coming years. In particular, a decrease of $50 \%$ by 2020 was forecast with respect to the current cost [38]. In this case the proposed system will have a LCOE very close to that of a natural gas combined cycle power plant integrated with calcium looping $\left(\sim 0.048 € \cdot \mathrm{kWh}^{-1}\right)$ and a better AC $\left(\sim 23 € \cdot\right.$ tCO2$\left.^{-1}\right)$.

To evaluate the daily profit (DP), the definition reported by Hanak et al. [21] was used:

$D P_{j}=R-\left[\left(\frac{S F C_{s_{2}}}{\eta_{n e t, j}}\right) E_{j}+K_{j}\right] \quad j=s_{2}, r e f$ 
where $R$ is the daily revenue from electricity sales, considering the same net power output for both proposed and reference systems (see $E_{n e t}$ in Table 1). The second term on the right-hand side of Eq. (19) is the daily operating costs associated with fuel consumption, by considering ESOFC and Enet for SE-SMR-SOFC and for the reference case, respectively. $K_{j}$ represents the daily operating costs associated with $\mathrm{CO}_{2}$ transport and storage, with $\mathrm{CO}_{2}$ emissions for natural gas-fired power plant. The net efficiency of the proposed and reference systems is 0.51 (see Table 1) and 0.55 (see Table 2), respectively.

The results are shown in Figure 5, where the spot price of electricity was also reported [21]. The proposed system is characterised by a higher daily profit than the reference plant (see dashed line which reports the difference $\left.D P P S-D P_{r e f}\right)$, with a daily revenue (29 k€, see solid line) of about $3 \mathrm{k} €$ more. In fact, with the parameters used for the base case (see Table 2), the cost of $\mathrm{CO}_{2}$ emission of the reference system (carbon tax of $18 € \cdot \mathrm{tcO}_{2}^{-1}$, see Table 2) is higher than the $\mathrm{CO}_{2}$ storage cost $\left(\mathrm{CO}_{2}\right.$ transport and storage cost of $7 € \cdot \mathrm{tCO}^{-1}$, see Table 2) of SE-SMR-SOFC. Further increase of the profit can be achieved by optimising the operating conditions of SE-SMR process, in order to decrease the required number of reactors. In this case, the net power generation is higher since the heat supplied by the burner is lower, as well as its electricity demand.

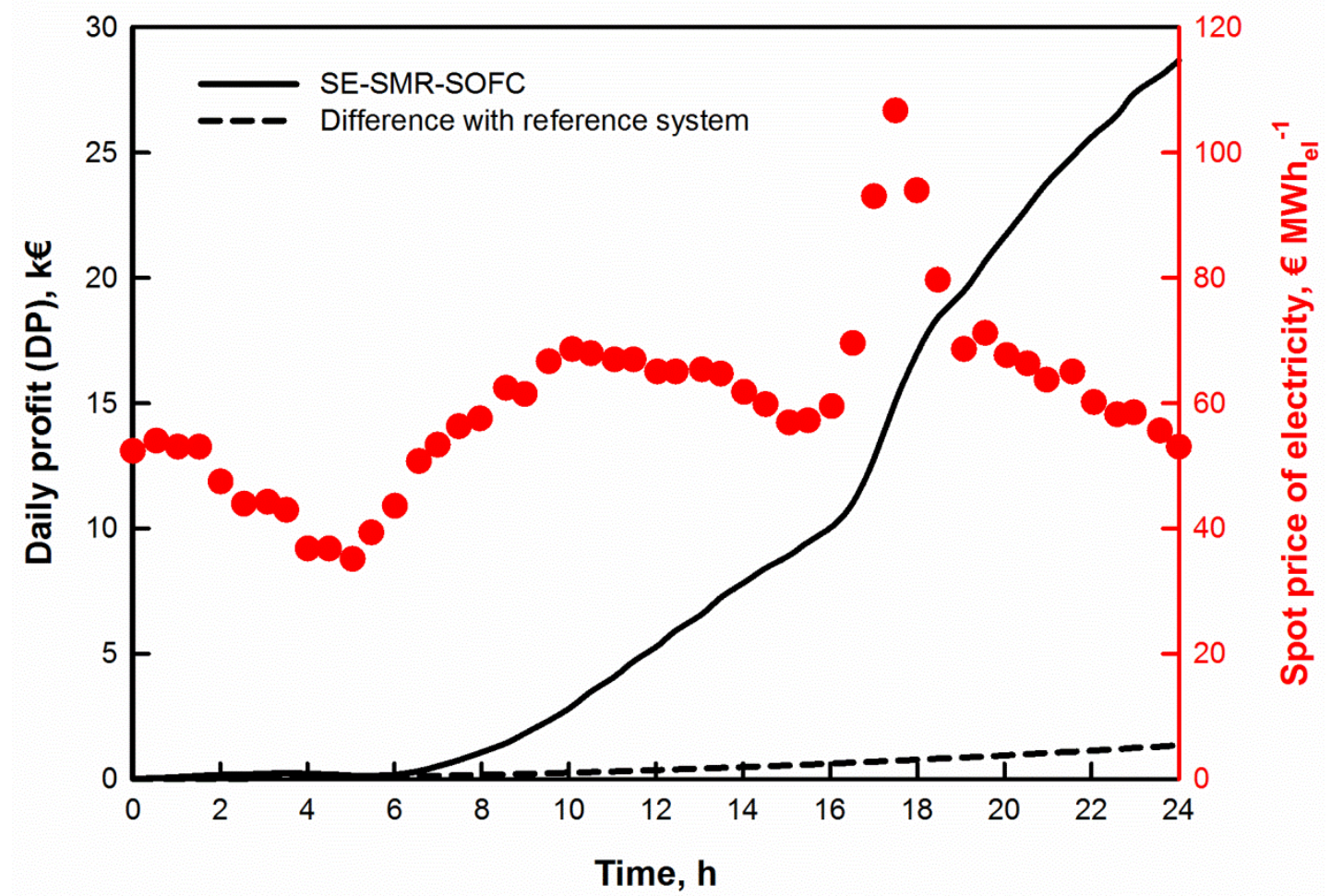

Figure 5 - Daily profit of SE-SMR-SOFC (solid line), difference between DP of SE-SMR-SOFC and that of reference system (dashed line) and spot price of electricity (red dot). 
4.4. Economic performance of SE-SMR-SOFC-Sensitivity Analysis

Figure 6 a shows the results of the sensitivity analysis in term of LCOE, while Figure $6 \mathrm{~b}$ shows AC. Since the majority of the investment cost for SE-SMR-SOFC is for the capital cost of the SOFC (80.2\%, see Figure 4), this latter has the strongest impact on both LCOE (-5.4\% to $5.1 \%)$ and AC ($11.9 \%$ to $10.6 \%$ ). Even though the impact is smaller than in the SE-SMR system, due to the large influence of SOFC cost on TCR, in this case the economic performance of the system is highly affected by the specific cost of fuel (LCOE varies between $\pm 3 \%$ and $\mathrm{AC}$ between \pm 0.5 ). By varying the cost of the burner, solids (catalyst and sorbent) and reactor (steel and refractory), the trends of LCOE and AC are the same as those of SE-SMR (for which LCOH is the equivalent of LCOE). 
a)

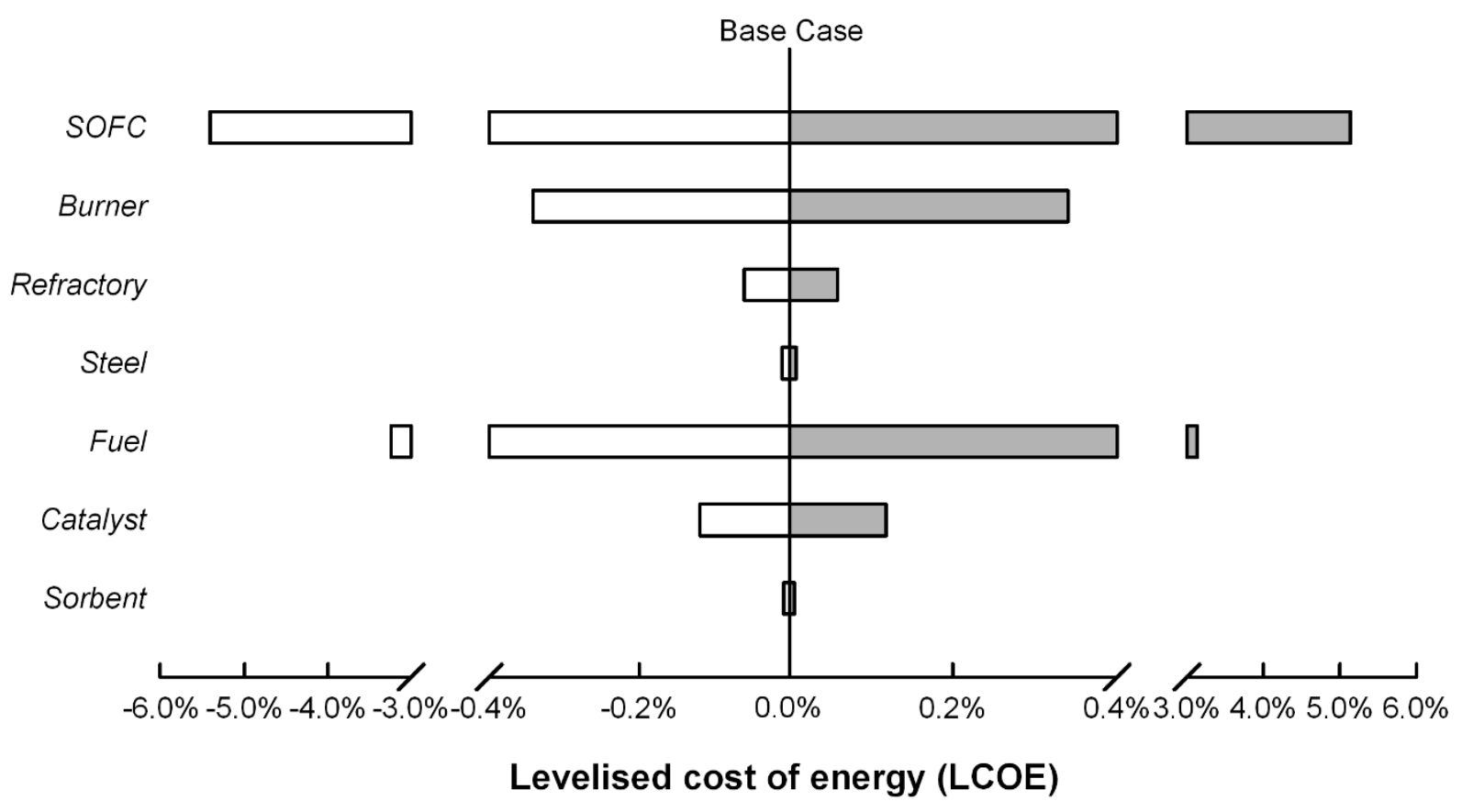

$\square-10 \% \square+10 \%$

b)

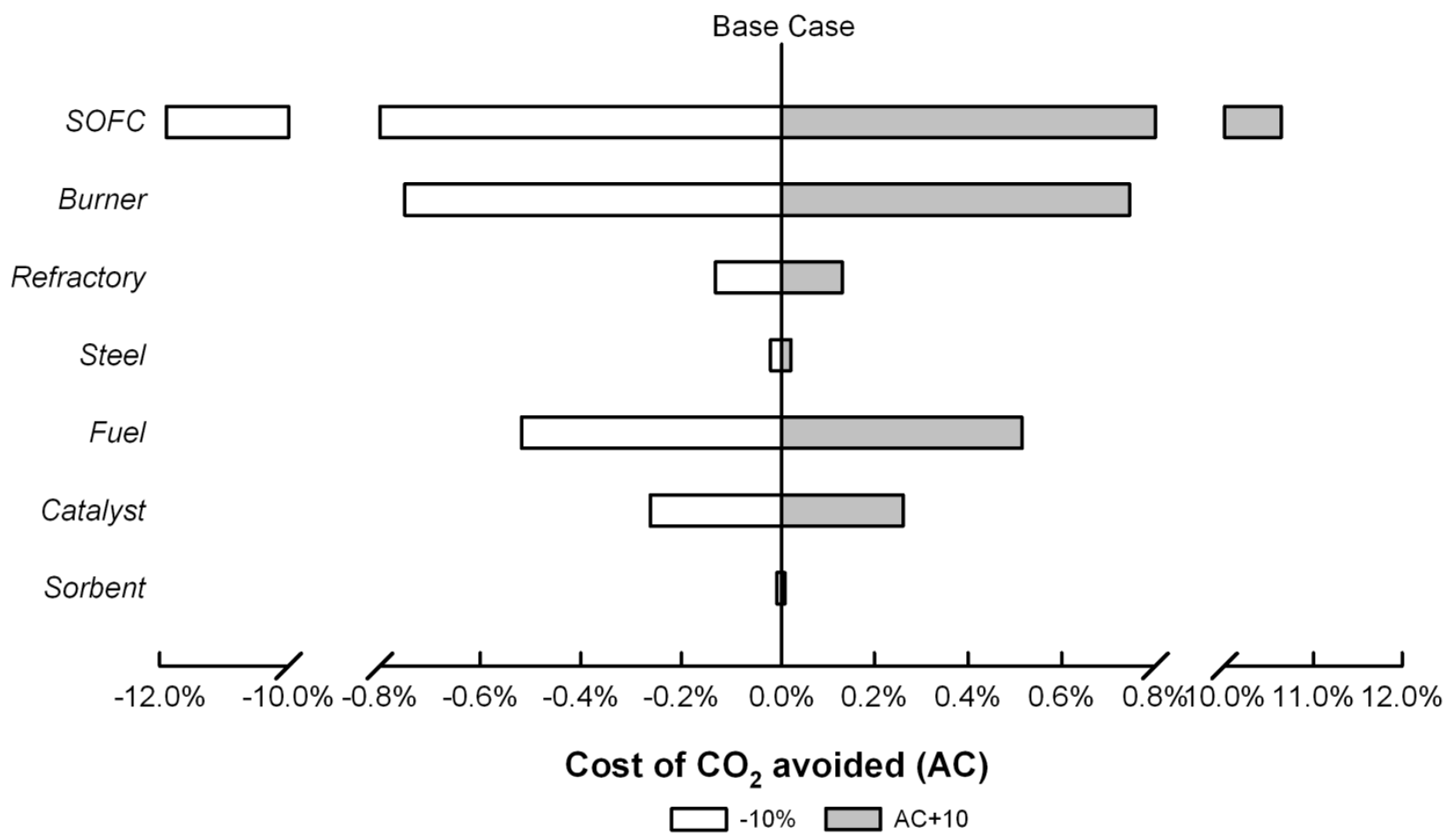

Figure 6 - SE-SMR-SOFC LCOE (a) and AC SE-SMR-SOFC (b) sensitivity analysis. 
The daily profit is strongly affected by the price of electricity, which depends on several parameters such as weather conditions, intensity of business and everyday activities, and calendar day (holiday or work day). Figure 7 reports the daily revenue varying the spot price of electricity (SPE) in the range $\pm 10 \%$ with respect to the base case (Figure 5). In the best-case scenario the daily revenue of SE-SMR-SOFC was about $36.5 \mathrm{k} €$, which decreases to $21.4 \mathrm{k} €$ in the worst case. The daily profit is extremely sensitive to changes in the price of electricity. To better understand it, the daily revenue can be expressed with reference to daily electricity generation (specific daily revenue): the value of this index is $\sim 1.6 \mathrm{k} € \cdot \mathrm{MWh}_{\mathrm{el}}{ }^{-1}$ in the base case and decreases from 2 to $1.2 \mathrm{k} € \cdot \mathrm{MWh}_{\mathrm{el}}{ }^{-1}$ by varying SPE in the range $\pm 10 \%$. Thus, passing from the best- to the worst-case scenario, the specific daily revenue decreases about $50 \%$.

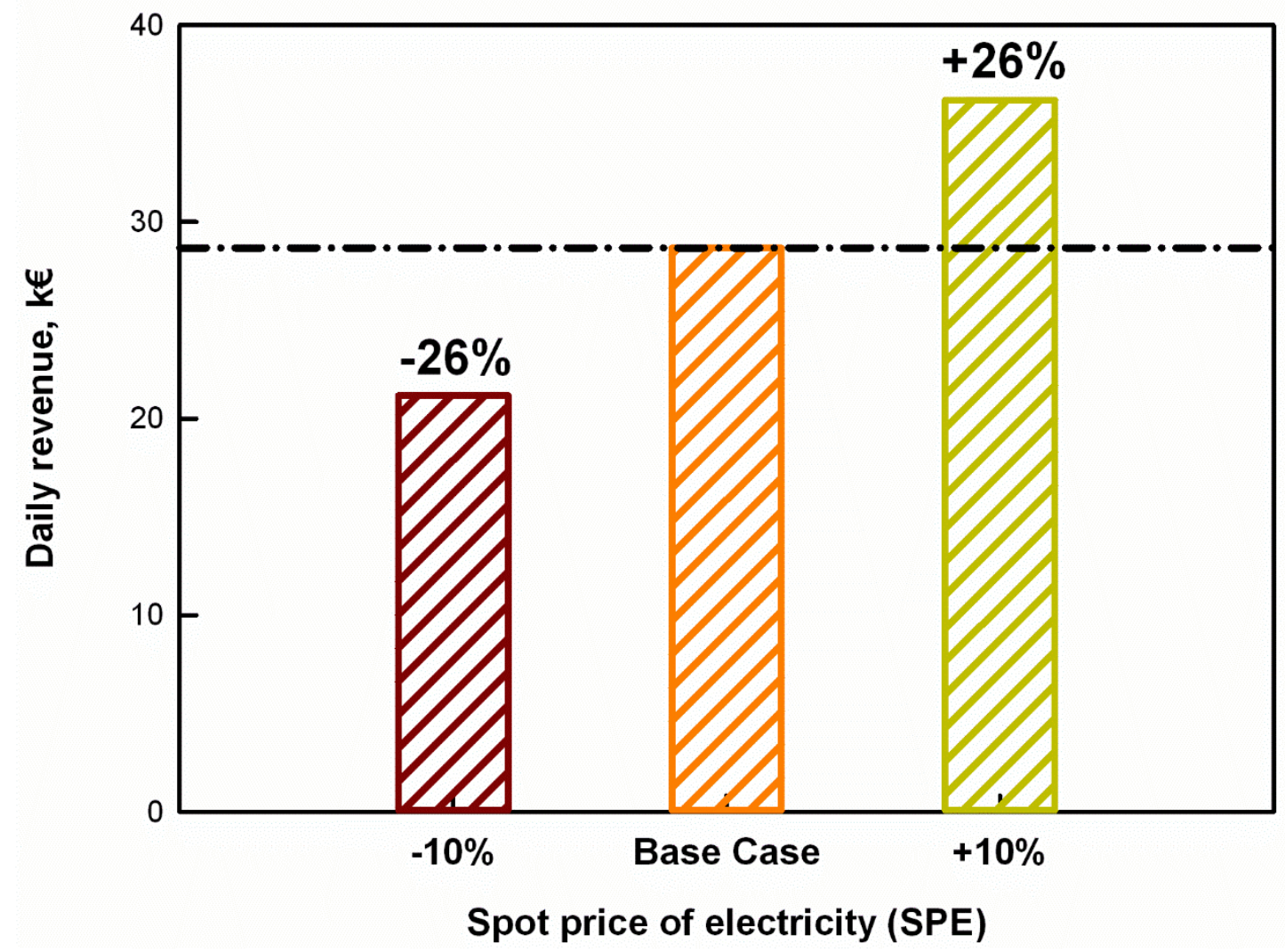

Figure 7 - Sensitivity analysis of daily revenue by varying the spot price of electricity.

The economic performance of a power generation system, both with and without $\mathrm{CO}_{2}$ capture, is highly dependent upon the economic climate, as the $\mathrm{CO}_{2}$ transport and storage cost may vary between 5 and $33 € \cdot \operatorname{tcO}^{-1}$ [39] and the carbon tax is predicted to vary between 10 and $150 € \cdot \operatorname{tcO}^{-1}$ [40]. Figure 8 shows the results of the sensitivity analysis on CTS and CT. In particular, Figure 8A 
reports the daily revenue of SE-SMR-SOFC (red line) and the difference between the daily revenue of the proposed system and that of the reference system (green line) by varying CTS, while Figure $8 \mathrm{~B}$ reports the daily revenue of reference system (red line) and the difference between the daily revenue of SE-SMR-SOFC and that of the reference system (green line) by varying CT. The daily revenue of SE-SMR-SOFC decreases by increasing CTS. Since the daily profit of the reference system is constant, also the difference between the daily revenue of the proposed system and the reference one decreases with the increase of CTS. By keeping the carbon tax constant at $18 € \cdot \mathrm{tCO}^{-1}$ (base case, see Table 2), when the $\mathrm{CO}_{2}$ transport and storage cost exceeds $12 € \cdot \mathrm{t}_{\mathrm{CO}}{ }^{-1}$ the reference system becomes more profitable than the proposed one (green line drops below zero in Figure 8A). On the contrary, the daily revenue of the reference system decreases with the increase of CT. Since the daily profit of the proposed system is constant, the difference between the daily revenue of the proposed system and the reference one increases with CTS. In this case, by keeping the CTS constant at $7 € \cdot \mathrm{tCO}^{-1}$ (base case, see Table 2), SE-SMR-SOFC is more profitable than a conventional natural gas-fired power plant only when the carbon tax surpasses $12 € \cdot \mathrm{tcO}^{-1}$ (green line exceeds zero in Figure $8 \mathrm{~B}$ ). Thus, it can be inferred that the proposed solution is preferable to the reference one only when the difference between the carbon tax and the $\mathrm{CO}_{2}$ transport and storage cost is higher than $6 € \cdot \mathrm{tCO}^{-1}$.
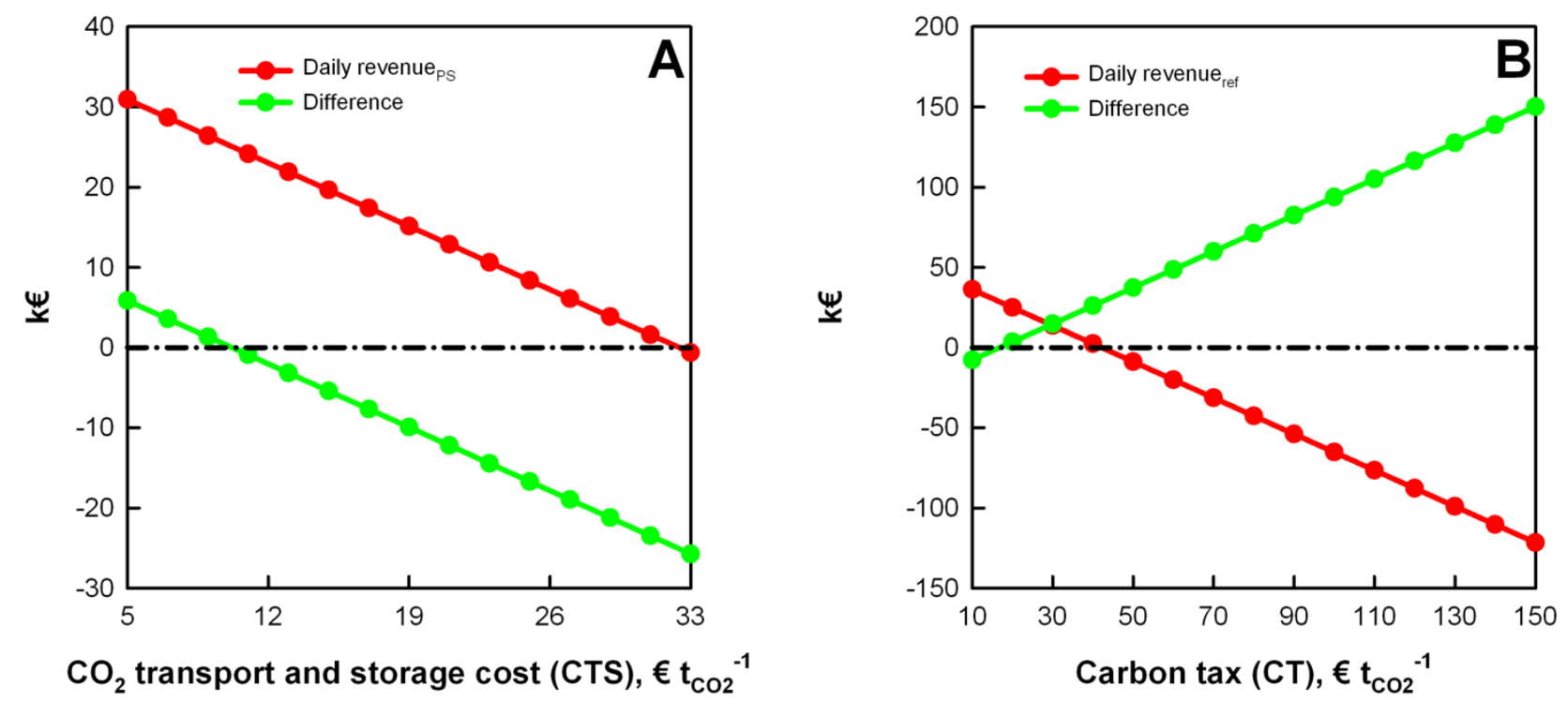

Figure 8 - Sensitivity analysis of daily revenue of SE-SMR-SOFC (red line) and difference between daily revenue of SE-SMR-SOFC and that of reference system (green line) by varying CTS (A); sensitivity analysis of daily revenue of reference system (red line) and difference between daily revenue of SE-SMR-SOFC and that of reference system (green line) by varying $C T(B)$. 


\section{Conclusions}

In this study, the techno-economic performance of hydrogen production (SE-SMR) and power generation (SE-SMR-SOFC) concepts accomplished with production of a pure $\mathrm{CO}_{2}$ stream were assessed. The first system consisted of a network of 8 packed bed reactors in which sorption-enhanced steam methane reforming is carried out. The energetically self-sufficient conditions are reached by burning, in an external combustor, part of the produced $\mathrm{H}_{2}$ to cover heat demand of SE-SMR. In the second system a portion of the $\mathrm{H}_{2}$ produced by SE-SMR is fed to an external burner to meet heat demand of the system and the remaining part is sent to a SOFC for power generation.

The analysis revealed that the total capital costs of SE-SMR and SE-SMR-SOFC are strongly affected by the reactor network (70\% of the total) and SOFC capital cost ( $80.2 \%$ of the total), respectively. Both proposed systems demonstrated better economic performance than the reference cases. In the first case the costs of produced $\mathrm{H}_{2}$ and $\mathrm{CO}_{2}$ avoided are $1.6 € \cdot \mathrm{kg}^{-1}$ and $29.85 € \cdot \mathrm{tCO}^{-1}$, respectively. These are about $33 \%$ and $40 \%$ lower than that of conventional SMR with $\mathrm{CO}_{2}$ capture, respectively. In the second case the levelised cost of electricity and the cost of $\mathrm{CO}_{2}$ avoided are $0.078 € \cdot \mathrm{kWh}$ and $36.83 € \cdot \mathrm{tcO}^{-1}$, i.e., about $2.5 \%$ and $54 \%$ lower than those of a natural gas-fired power plant with post-combustion capture system, respectively. The daily revenue of SE-SMR-SOFC was $29 \mathrm{k} €$, about $3 \mathrm{k} €$ higher than that of a natural gas-fired power plant without $\mathrm{CO}_{2}$ capture.

The sensitivity analysis showed that the economic performance of SE-SMR is mainly affected by the specific cost of fuel, while the capital cost of SOFC is the predominant parameter for SE-SMRSOFC. Moreover, the analysis highlighted that the specific daily revenue of SE-SMR-SOFC is about $1.6 \mathrm{k} € \cdot \mathrm{MWh}_{\mathrm{el}}{ }^{-1}$ in the base case. It decreases from 2 to $1.2 \mathrm{k} € \cdot \mathrm{MWh}_{\mathrm{el}}{ }^{-1}$ by varying the spot price of electricity in the range $\pm 10 \%$ with respect to the base case. Finally, the sensitivity analysis proved that SE-SMR-SOFC is more profitable than the natural gas-fired power plant only when the difference between the carbon tax and the $\mathrm{CO}_{2}$ transport and storage cost is higher than $6 € \cdot \mathrm{tcO}^{-1}$. 


\section{References}

[1] I.E.A. (IEA), World Energy Outlook, Paris, 2015.

[2] G. Marbán, T. Valdés-Solís, Towards the hydrogen economy?, Int. J. Hydrogen Energy. 32 (2007) 1625-1637. doi:10.1016/j.ijhydene.2006.12.017.

[3] C.D. Bohn, C.R. Müller, J.P. Cleeton, A.N. Hayhurst, J.F. Davidson, S.A. Scott, et al., Production of Very Pure Hydrogen with Simultaneous Capture of Carbon Dioxide using the Redox Reactions of Iron Oxides in Packed Beds, Ind. Eng. Chem. Res. 47 (2008) 76237630. doi:10.1021/ie800335j.

[4] G. Diglio, P. Bareschino, E. Mancusi, F. Pepe, Simulation of Hydrogen Production through Chemical Looping Reforming Process in a Packed-Bed Reactor, Chem. Eng. Res. Des. 105 (2015) 137-151. doi:10.1016/j.cherd.2015.11.013.

[5] G. Diglio, P. Bareschino, R. Solimene, E. Mancusi, F. Pepe, P. Salatino, Numerical simulation of hydrogen production by chemical looping reforming in a dual fluidized bed reactor, Powder Technol. 316 (2017) 614-627. doi:10.1016/j.powtec.2016.12.051.

[6] G. Diglio, P. Bareschino, E. Mancusi, F. Pepe, Novel quasi -autothermal hydrogen production process in a fixed-bed using a chemical looping approach: A numerical study, Int. J. Hydrogen Energy. 42 (2017) 15010-15023. doi:10.1016/j.ijhydene.2017.05.017.

[7] N. Berghout, M. van den Broek, A. Faaij, Techno-economic performance and challenges of applying $\mathrm{CO}_{2}$ capture in the industry: A case study of five industrial plants, Int. J. Greenh. Gas Control. 17 (2013) 259-279. doi:10.1016/j.ijggc.2013.04.022.

[8] L. Zhu, J. Fan, Thermodynamic analysis of н2 production from $\mathrm{CaO}$ sorption-enhanced methane steam reforming thermally coupled with chemical looping combustion as a novel technology, Int. J. Energy Res. 39 (2015) 356-369. doi:10.1002/er.3248.

[9] D.P. Hanak, E.J. Anthony, V. Manovic, A review of developments in pilot plant testing and modelling of calcium looping process for $\mathrm{CO}_{2}$ capture from power generation systems, Energy Environ. Sci. 8 (2015) 2199-2249. doi:10.1039/c5ee01228g.

[10] V. Manovic, E.J. Anthony, CaO-based pellets with oxygen carriers and catalysts, Energy and Fuels. 25 (2011) 4846-4853. doi:10.1021/ef2009748.

[11] K. Johnsen, H.J. Ryu, J.R. Grace, C.J. Lim, Sorption-enhanced steam reforming of methane in a fluidized bed reactor with dolomite as $\mathrm{CO}_{2}$-acceptor, Chem. Eng. Sci. 61 (2006) 11951202. doi:10.1016/j.ces.2005.08.022.

[12] K. Johnsen, J.R. Grace, S.S.E.H. Elnashaie, L. Kolbeinsen, D. Eriksen, Modeling of sorption-enhanced steam reforming in a dual fluidized bubbling bed reactor, Ind. Eng. Chem. Res. 45 (2006) 4133-4144. doi:10.1021/ie0511736.

[13] J.R. Fernández, I. Martínez, J.C. Abanades, M.C. Romano, Conceptual design of a Ca-Cu chemical looping process for hydrogen production in integrated steelworks, Int. J. Hydrogen Energy. 42 (2017) 11023-11037. doi:10.1016/j.ijhydene.2017.02.141.

[14] G. Diglio, P. Bareschino, E. Mancusi, F. Pepe, Numerical assessment of the effects of carbon deposition and oxidation on chemical looping combustion in a packed-bed reactor, Chem. Eng. Sci. 160 (2017) 85-95. doi:10.1016/j.ces.2016.11.020.

[15] Z. Li, N. Cai, J. Yang, Continuous Production of Hydrogen from Sorption-Enhanced Steam Methane Reforming in Two Parallel Fixed-Bed Reactors Operated in a Cyclic Manner, Ind. Eng. Chem. Res. 45 (2006) 8788-8793. doi:10.1021/ie061010x.

[16] A. Antzara, E. Heracleous, A.A. Lemonidou, Energy efficient sorption enhanced-chemical 
looping methane reforming process for high-purity $\mathrm{H}_{2}$ production: Experimental proof-ofconcept, Appl. Energy. 180 (2016) 457-471. doi:10.1016/j.apenergy.2016.08.005.

[17] J.R. Fernandez, J.C. Abanades, R. Murillo, Modeling of sorption enhanced steam methane reforming in an adiabatic fixed bed reactor, Chem. Eng. Sci. 84 (2012) 1-11. doi:10.1016/j.ces.2012.07.039.

[18] Z.S. Li, N.S. Cai, Modeling of multiple cycles for sorption-enhanced steam methane reforming and sorbent regeneration in fixed bed reactor, Energy and Fuels. 21 (2007) 29092918. doi:10.1021/ef070112c.

[19] G. Diglio, D. Hanak, P. Bareschino, F. Pepe, F. Montagnaro, V. Manovic, Modelling of sorption-enhanced steam methane reforming in a fixed bed reactor network integrated with fuel cell, in preparation (2017).

[20] IEA, Technology Roadmap, SpringerReference. (2015) 81. doi:10.1007/SpringerReference_7300.

[21] D.P. Hanak, D. Powell, V. Manovic, Techno-economic analysis of oxy-combustion coalfired power plant with cryogenic oxygen storage, Appl. Energy. 191 (2017) 193-203. doi:10.1016/j.apenergy.2017.01.049.

[22] M. Erans, D.P. Hanak, J. Mir, E.J. Anthony, V. Manovic, Process modelling and technoeconomic analysis of natural gas combined cycle integrated with calcium looping, Therm. Sci. 20 (2016) S59-S67. doi:10.2298/TSCI151001209E.

[23] H.P. Hamers, M.C. Romano, V. Spallina, P. Chiesa, F. Gallucci, M. van Sint Annaland, Energy analysis of two stage packed-bed chemical looping combustion configurations for integrated gasification combined cycles, Energy. 85 (2015) 489-502. doi:10.1016/j.energy.2015.03.063.

[24] P. Fennell, B. Anthony, Calcium and Chemical Looping Technology for Power Generation and Carbon Dioxide $\left(\mathrm{CO}_{2}\right)$ Capture, 2015.

http://www.sciencedirect.com/science/book/9780857092434.

[25] Agilent Technologies Italia - Vacuum pumps - product technical data, (www.agilent.com, last accessed 26/05/2017).

[26] S. Simoes, W. Nijs, P. Ruiz, A. Sgobbi, D. Radu, P. Bolat, et al., The JRC-EU-TIMES model. Assessing the long-term role of the SET Plan Energy technologies, 2013. doi:10.2790/97596.

[27] A. Arsalis, Thermoeconomic modeling and parametric study of hybrid SOFC-gas turbinesteam turbine power plants ranging from 1.5 to 10 MWe, J. Power Sources. 181 (2008) 313326. doi:10.1016/j.jpowsour.2007.11.104.

[28] N. Muradov, Low to near-zero $\mathrm{CO}_{2}$ production of hydrogen from fossil fuels: Status and perspectives, Int. J. Hydrogen Energy. 42 (2017) 14058-14088.

doi:10.1016/j.ijhydene.2017.04.101.

[29] B. Metz, O. Davidson, H. de Coninck, M. Loos, L. Meyer, IPCC Special Report on Carbon Dioxide Capture and Storage, 2005. doi:10.1021/es200619j.

[30] H.P. Hamers, M.C. Romano, V. Spallina, P. Chiesa, F. Gallucci, M.V.S. Annaland, Comparison on process efficiency for CLC of syngas operated in packed bed and fluidized bed reactors, Int. J. Greenh. Gas Control. 28 (2014) 65-78. doi:10.1016/j.ijggc.2014.06.007.

[31] R. Perry, D.W. Green, Chemical Engineer's Handbook, 7th ed., New York, USA, 1997.

[32] M.N. Khan, T. Shamim, Techno-economic assessment of a plant based on a three reactor 
chemical looping reforming system, Int. J. Hydrogen Energy. 41 (2016) 22677-22688. doi:10.1016/j.ijhydene.2016.09.016.

[33] V. Spallina, A. Shams, A. Battistella, F. Gallucci, M. Van, Chemical Looping Technologies For $\mathrm{H}_{2}$ Production With $\mathrm{CO}_{2}$ Capture : Thermodynamic Assessment And Economic Comparison, Energy Procedia. 144 (2017) 419-428.

[34] S. Velumani, C. Enrique Guzman, R. Peniche, R. Vega, Proposal of a hybrid CHP system: SOFC/microturbine/absorption chiller, Int. J. Energy Res. 34 (2010) 1088-1095. doi:10.1002/er.1632.

[35] A.L. Facci, V. Cigolotti, E. Jannelli, S. Ubertini, Technical and economic assessment of a SOFC-based energy system for combined cooling, heating and power, Appl. Energy. 192 (2017) 563-574. doi:10.1016/j.apenergy.2016.06.105.

[36] Y. Hu, G. Xu, C. Xu, Y. Yang, Thermodynamic analysis and techno-economic evaluation of an integrated natural gas combined cycle (NGCC) power plant with post-combustion $\mathrm{CO}_{2}$ capture, Appl. Therm. Eng. 111 (2017) 308-316. doi:10.1016/j.applthermaleng.2016.09.094.

[37] C.C. Cormos, Assessment of chemical absorption/adsorption for post-combustion $\mathrm{CO}_{2}$ capture from Natural Gas Combined Cycle (NGCC) power plants, Appl. Therm. Eng. 82 (2015) 120-128. doi:10.1016/j.applthermaleng.2015.02.054.

[38] A. Wilson, J. Marcinkoski, D. Papageorgopoulos, R. Ahluwalia, B. James, C. Houchins, et al., DOE Hydrogen and Fuel Cells Program Record Title: Fuel Cell System Cost -2016 Originator, (2016) 1-9.

[39] E.S. Rubin, C. Short, G. Booras, J. Davison, C. Ekstrom, M. Matuszewski, et al., A proposed methodology for $\mathrm{CO}_{2}$ capture and storage cost estimates, Int. J. Greenh. Gas Control. 17 (2013) 488-503. doi:10.1016/j.ijggc.2013.06.004.

[40] D.P. Hanak, C. Biliyok, V. Manovic, Calcium looping with inherent energy storage for decarbonisation of coal-fired power plant, Energy Environ. Sci. 9 (2016) 971-983. doi:10.1039/C5EE02950C. 